\title{
Hereditary Cancer Risk Assessment: How Best can we Achieve it?
}

Israel Gomy* and Maria Del Pilar Estevez Diz

Sao Paulo Cancer Institute, Sao Paulo, Brazil

\begin{abstract}
Hereditary cancer risk assessment (HCRA) is a multidisciplinary process of estimating probabilities of germline mutations in cancer susceptibility genes and assessing empiric risks of cancer, based on personal and family histories. It includes genetic testing and management of at-risk individuals so that they can make informed choices about cancer screening, surgical and chemo preventive options, as well as genetically targeted cancer therapies. Providing patients with pre- and post-test genetic counseling may help them to get better informed decision making. Following individuals at increased risk with surveillance protocols, reassuring those at low risk, and referring those at high risk of a hereditary cancer to a cancer genetics center with outpatient clinics may be the best suitable approach to HCRA.
\end{abstract}

Keywords: Hereditary; Cancer; Mutations; Genetic testing

\section{Introduction}

Within the last decade, emerging biomolecular technologies have been continuing to grow fast and have already achieved a great deal in our understanding of inherited cancer susceptibility. Meanwhile, important issues on the translation of this knowledge into clinical practice have been rapidly addressed. One essential component of these aspects refers to genetic counseling of families with hereditary cancer syndromes. The increased public awareness of the genetic aspects of cancer susceptibility has resulted in more requests from clinical and surgical oncologists for genetic evaluation of their patients so that appropriate management can be provided.

Five to $10 \%$ of all cancers are attributable to more than fifty Mundelein syndromes which are caused by highly penetrant germ-line mutations affecting tumor suppressor genes or proto-oncogenes mostly as an autosomal dominant inheritance (Tables 1 and 2). The cumulative risks of hereditary cancers are much higher and earlier than sporadic counterparts, which dramatically affect quality of life and decrease its expectancy. Other than an earlier than expected age of cancer diagnosis (e.g., colon cancer diagnosed before age 50 years), family history is the single most important indicator of strong hereditary cancer risk for which early recognition and intervention could be lifesaving.

This review aimed to describe a high-quality approach of delivering hereditary cancer risk assessment (HCRA) in the context of a multidisciplinary clinic.

\section{Referrals for Hcra}

Identifying the inherited risk factors of cancer in a given individual or family is complex raising important psychological, social, and ethical issues. It requires knowledge of genetics, oncology, patient and family counseling skills and involves more provider time than most other clinical services. The American Society of Clinical Oncology (ASCO), the National Society of Genetic Counselors (NSGC), the Oncology Nursing Society (ONS), and other health care professional organizations have set forth guidelines outlining standards for the practice of cancer risk counseling, risk assessment, and genetic testing [1-3]. It also includes genetic testing as appropriate and management of at-risk individuals so that they can make informed choices about cancer screening and surgical and/or chemo preventive risk management options, as well as genetically targeted cancer therapies [4].

\section{Components of the Hcra}

The genetic risk assessment of an individual with cancer is based upon a careful analysis of personal history, a detailed family history of cancer and a physical examination when appropriate. It requires the confirmation of diagnosis in affected relatives, preferably through biopsies or, whenever possible, death certificates or autopsies.

These are some important issues to be addressed in the HCRA process [4]:

1. Family pedigrees drawings with at least three generations in both sides of family

2. Patients and relatives:

$\alpha$. Current age, age at diagnosis, age at death, primary site, pathologic features, treatments

3. Ancestry (especially if Ashkenazi Jewish)

$\chi$. Previous surgeries, biopsies, diseases

$\delta$. Endogenous risk factors: age at menarche, fertility history

ع. Exogenous risk factors: tobacco/alcohol use, food intake, hormones, exercises

$\phi$. Cancer screening: mammography, gastrointestinal endoscopy, PSA

$\gamma$. Chemoprevention

3. Physical examination (when appropriate): skin, head circumference, tongue, thyroid, lungs, abdomen

4. Psychosocial and family dynamic

5. Basic principles of cancer genetics

6. Differential diagnosis

7. Mutation probabilities and empirical risks

8. Pre-test genetic counseling

$\alpha$. Indentify the best individuals to test

$\beta$. Prioritize order of testing (germ-line, tumor)

*Corresponding author: Israel Gomy, MD, PhD, Cancer geneticist, Sao Paulo Cancer Institute, Sao Paulo, Brazil, Tel: +55 11 29250500; E-mail: israel.gomy@icesp.org.br

Received April 26, 2013; Accepted May 06, 2013; Published May 18, 2013

Citation: Gomy I, Estevez Diz MDP (2013) Hereditary Cancer Risk Assessment: How Best can we Achieve it? Genetics S2: 003. doi:10.4172/2161-1041.S2-003

Copyright: @ 2013 Gomy I. This is an open-access article distributed under the terms of the Creative Commons Attribution License, which permits unrestricted use, distribution, and reproduction in any medium, provided the original author and source are credited. 
$\chi$. Explain test techniques, limitations, sensitivity/specificity

$\delta$. Facilitate informed consent: possible outcomes (positive, truenegative, uninformative); costs; turn-around-time; insurance coverage

E. Address psychological, ethical, cultural, communication issues

\begin{tabular}{|c|c|c|c|}
\hline Syndrome (s) & Gene (s) & Inheritance & Principal tumors \\
\hline $\begin{array}{l}\text { Hereditary breast and } \\
\text { ovarian cancer }\end{array}$ & $\begin{array}{l}\text { BRCA1 } \\
\text { BRCA2 }\end{array}$ & Autosomal dominant & $\begin{array}{l}\text { Breast cancer } \\
\text { Ovarian cancer } \\
\text { Pancreatic cancer } \\
\text { Prostate cancer }\end{array}$ \\
\hline $\begin{array}{l}\text { Lynch syndrome } \\
\text { (formerly HNPCC) } \\
\text { includes Muir-Torre, } \\
\text { Turcot syndrome }\end{array}$ & $\begin{array}{l}\text { MLH1 } \\
\text { MSH2 } \\
\text { MSH6 } \\
\text { PMS2 } \\
\text { EPCAM }\end{array}$ & Autosomal dominant & $\begin{array}{l}\text { Colorectal cancer } \\
\text { Endometrial cancer } \\
\text { Ovarian cancer } \\
\text { Gastric cancer } \\
\text { Urothelial/biliar tract } \\
\text { cancer }\end{array}$ \\
\hline $\begin{array}{l}\text { Familial adenomatous } \\
\text { polyposis (includes } \\
\text { Gardner syndrome) }\end{array}$ & APC & Autosomal dominant & $\begin{array}{l}\text { Gastrointestinal } \\
\text { adenomas } \\
\text { Colorectal cancer } \\
\text { Duodenal cancer }\end{array}$ \\
\hline $\begin{array}{l}\text { MYH-associated } \\
\text { polyposis }\end{array}$ & MUTYH & Autosomal recessive & Colorectal cancer \\
\hline $\begin{array}{l}\text { Li-Fraumeni } \\
\text { syndrome }\end{array}$ & TP53 & Autosomal dominant & $\begin{array}{l}\text { Sarcoma } \\
\text { Adrenocortical cancer } \\
\text { Brain tumor (include } \\
\text { choroid plexus) } \\
\text { Breast cancer }\end{array}$ \\
\hline Cowden syndrome & PTEN & Autosomal dominant & $\begin{array}{l}\text { Skin tumors } \\
\text { Breast cancer } \\
\text { Thyroid cancer } \\
\text { Endometrial cancer }\end{array}$ \\
\hline $\begin{array}{l}\text { Hereditary diffuse } \\
\text { gastric cancer }\end{array}$ & $\mathrm{CDH} 1$ & Autosomal dominant & $\begin{array}{l}\text { Gastric cancer (diffuse) } \\
\text { Breast cancer (lobular) }\end{array}$ \\
\hline $\begin{array}{l}\text { Peutz-Jeghers } \\
\text { syndrome }\end{array}$ & STK11 & Autosomal dominant & $\begin{array}{l}\text { Colorectal } \\
\text { Small bowel } \\
\text { Breast cancer } \\
\text { Pancreatic cancer }\end{array}$ \\
\hline Juvenile polyposis & $\begin{array}{l}\text { SMAD4 } \\
\text { BMPR1A }\end{array}$ & Autosomal dominant & $\begin{array}{l}\text { Colorectal cancer } \\
\text { Pancreatic cancer }\end{array}$ \\
\hline Melanoma syndromes & $\begin{array}{l}\text { CDKN2A } \\
(\mathrm{p} 16) \\
\text { CDK4 }\end{array}$ & Autosomal dominant & $\begin{array}{l}\text { Malignant melanoma } \\
\text { Pancreatic cancer }\end{array}$ \\
\hline Neurofibromatosis & $\begin{array}{l}\text { NF1 } \\
\text { NF2 }\end{array}$ & Autosomal dominant & $\begin{array}{l}\text { Schwannoma (vestibular) } \\
\text { Meningioma } \\
\text { Neurofibroma } \\
\text { Optic glioma }\end{array}$ \\
\hline Tuberous sclerosis & $\begin{array}{l}\text { TSC1 } \\
\text { TSC2 }\end{array}$ & Autosomal dominant & $\begin{array}{l}\text { Renal angiomyolipoma } \\
\text { Subependimoma } \\
\text { Astrocytoma(giant cell) }\end{array}$ \\
\hline $\begin{array}{l}\text { Von Hippel-Lindau } \\
\text { syndrome }\end{array}$ & VHL & Autosomal dominant & $\begin{array}{l}\text { Hemangioblastoma } \\
\text { (CNS, retina) } \\
\text { Renal cell cancer } \\
\text { Pheochromocytoma }\end{array}$ \\
\hline $\begin{array}{l}\text { Birt-Hogg-Dube } \\
\text { syndrome }\end{array}$ & FLCN & Autosomal dominant & $\begin{array}{l}\text { Renal cell cancer } \\
\text { Skin tumors }\end{array}$ \\
\hline $\begin{array}{l}\text { Papillary renal cancer } \\
\text { syndromes }\end{array}$ & $\begin{array}{l}\text { FH } \\
\text { MET }\end{array}$ & Autosomal dominant & Renal cell cancer \\
\hline Retinoblastoma & RB1 & Autosomal dominant & $\begin{array}{l}\text { Retinoblastoma } \\
\text { Osteosarcoma }\end{array}$ \\
\hline $\begin{array}{l}\text { Hereditary } \\
\text { Paraganglioma }\end{array}$ & $\begin{array}{l}\text { SDHA } \\
\text { SDHB } \\
\text { SDHC } \\
\text { SDHD }\end{array}$ & Autosomal dominant & $\begin{array}{l}\text { Paraganglioma } \\
\text { Pheochromocytoma }\end{array}$ \\
\hline $\begin{array}{l}\text { MEN1 } \\
\text { MEN2 }\end{array}$ & $\begin{array}{l}\text { MEN1 } \\
\text { RET }\end{array}$ & Autosomal dominant & $\begin{array}{l}\text { Pituitary adenoma } \\
\text { Parathyroid adenoma } \\
\text { Thyroid cancer (medular) } \\
\text { Pheochromocytoma }\end{array}$ \\
\hline
\end{tabular}

HNPCC: Hereditary Non Polyposis Colon Cancer

MEN: Multiple Endocrine Neoplasia

Table 1: Hereditary cancer syndromes.
9. Post-test genetic counseling

$\alpha$. Disclosure and interpretation of results

$\beta$. Address psychological and ethical concerns

$\chi$. Identify at-risk family members

$\delta$. Discuss communication of results to at-risk family members

10. Personalized risk management strategies

$\alpha$. Screening/surveillance exams

$\beta$. Risk reduction, cancer prevention (surgeries, chemoprevention)

$\chi$. Empiric strategies for uninformative results

\section{Predicting Germ line Mutations}

Several models are available to estimate the likelihood of detecting a mutation in a cancer-susceptibility gene and each model is utilized selectively based on the characteristics of the patient's personal and family history.

If a mutation in the BRCA gene is suspected to be present in a hereditary breast and ovarian cancer family, there are several models available to predict the probability of an individual carrying such a mutation. These models include the Couch, Penn II, Myriad, BRCAPRO, Tyrer-Cuzick, and BOADICEA models [5-12]. Such models incorporate breast and ovarian cancer in first- and seconddegree relatives, age of onset of cancer, Ashkenazi Jewish ancestry, and some are starting to incorporate other ethnic backgrounds.

There are similar models for predicting mutation in DNA mismatch repair (MMR) genes in suspected Lynch syndrome families, including MMRpro, Wijnen, MMRpredict, and PREMM1,2,6 [13-16]. However, in the HCRA of colon cancer families, it is more common to use established criteria as an indication for testing, including the Amsterdam I, Amsterdam II [17], or revised Bethesda Guidelines [18], which determine eligibility for tumor analysis to detect microsatellite instability that would help to lead to genetic testing of MMR genes.

Furthermore, there are established diagnostic criteria for $\mathrm{Li}$ and Fraumeni $[19,20]$ and Cowden syndromes [21,22], as well as mutation probability models for hereditary melanoma and pancreatic cancer (Table 3).

The use of mutation predictability models is important for several reasons. First, calculating the likelihood of a germ-line mutation can help clinicians determine which family member is the best candidate for testing. Second, due to the high cost of genetic testing, numeric calculations of mutation probability may provide supportive evidence for insurance companies. Third, for psychosocial reasons, patients who are informed with a numeric estimation of a mutation may have more realistic expectations about the possibility of a positive result. Finally, for worried patients with a low probability of a mutation, the numeric presentation may provide substantial reassurance regarding screening guidelines based on empiric cancer risks. A recent study highlighted possible health benefits and the cost-effectiveness of primary genetic screening for Lynch syndrome in the general population [23].

Nevertheless, several models may underestimate mutation probability in certain situations such as a limited family structure or specific tumor characteristics [24]. Thus, probabilities predicted by a model must be interpreted in the context of an individual's personal and family history. The National Comprehensive Cancer Network (NCCN) in USA publishes guidelines annually in order to help clinicians to 


\begin{tabular}{|l|l|}
\hline \multicolumn{1}{|c|}{ Personal history } & \multicolumn{1}{c|}{ Family history } \\
\hline $\begin{array}{l}\text { early onset of cancer diagnosis: } \\
\text { breast cancer }<45 \text { years, } \\
\text { colorectal cancer }<50 \text { years, etc. }\end{array}$ & $\begin{array}{l}\text { three close relatives (same side of family) } \\
\text { with cancer of the same or syndromically } \\
\text { related type (breast/ovary, colorectal/ } \\
\text { endometrium }\end{array}$ \\
\hline $\begin{array}{l}\text { multiple associated primary } \\
\text { cancers: breast/ovary, colorectal/ } \\
\text { endometrium }\end{array}$ & $\begin{array}{l}\text { two close relatives (same side of family) with } \\
\text { cancer of the same or related type with at } \\
\text { least one affected under } 50 \text { years }\end{array}$ \\
\hline male breast cancer & $\begin{array}{l}\text { one first-degree relative with early onset } \\
\text { cancer (breast < 45 years, colorectal <50 } \\
\text { years) }\end{array}$ \\
\hline $\begin{array}{l}\text { ovarian, fallopian tube, primary } \\
\text { peritoneal cancer }\end{array}$ & $\begin{array}{l}\text { one fist-degree relative with multiple primary } \\
\text { cancers }\end{array}$ \\
\hline $\begin{array}{l}\text { breast cancer and: thyroid, } \\
\text { sarcoma, adrenocortical } \\
\text { carcinoma }\end{array}$ & $\begin{array}{l}\text { Two or more relatives with uncommon } \\
\text { cancers (sarcoma, glioma, } \\
\text { hemangioblastoma, etc.) }\end{array}$ \\
\hline $\begin{array}{l}\text { multiple colon polyps }(>10 \\
\text { cumulative) }\end{array}$ & $\begin{array}{l}\text { relatives of patients with known BRCA, APC, } \\
\text { MYH, Lynch syndrome mutations }\end{array}$ \\
\hline $\begin{array}{l}\text { colorectal or endometrial } \\
\text { cancer with lack of expression } \\
\text { by immunohistochemistry for } \\
\text { mismatch repair protein }\end{array}$ & $\begin{array}{l}\text { many relatives with cancer but no criteria for } \\
\text { testing }\end{array}$ \\
\hline
\end{tabular}

Table 2: Possible indications of referrals for hereditary cancer risk assessment.

select which patients are appropriate candidates for genetic referral and genetic testing $[25,26]$.

\section{Predicting Cancer Risks}

In the absence of an identified gene mutation, counseling unaffected individuals about their empiric risk of cancer requires careful consideration of the patient's personal and family history.

Most risk estimates for cancer development are empiric, based on the probability of a genetic component in the individual, and this risk estimate increases if the proband has several affected relatives on the same side of family with the same or related cancers, multiple or early onset cancers, or if the individual has clinical features of a hereditary cancer syndrome [27].

For breast cancer, there are several models that estimate empiric risks, including the Gail et al. [28], Claus et al. [29], BRCAPRO [810], Tyrer et al. [11] and BOADICEA [12] models. All of these models incorporate first-degree relatives with breast cancer along with hormone risk factors; although they may vary in which known breast cancer risk factors are incorporated. There are also some published tools available to assess risks for colon, ovarian, lung, melanoma, and other cancers, but few are validated [30]. Numeric estimates of cancer risk may guide recommendations for appropriate screening and preventive care.

Because models used to convert genotypes into absolute risks are empirically derived, prospective research is needed to confirm the accuracy of these predictions and to evaluate the effectiveness of interventions based on individual genetic testing.

How should risks of developing cancer be communicated? They can be given as cancer risk per year, or before a certain age, or within a decade, or as an overall lifetime risk in comparison with the population risk in terms of relative risks. The individual perception of cancer risk should be assessed, as should its possible effects on the health and lifestyle behaviors.

\section{Pre-test Counseling}

After establishing risks of identifying a pathogenic germ-line mutation in a family and indicating the best candidates to be tested, it follows the information process of pre-test genetic counseling, which requires informed consent for testing for a genetic cancer susceptibility gene (Table 4). It is an approach that explains to the affected relative the nature of the tests to be carried out, the possible results (positive, negative, undetermined, inconclusive), the emotional impact they may cause, and its relevance regarding employment and insurance. This approach must be nondirective, letting patients make their own decisions after viewing all possible scenarios [31]. In numerous cases, a pathogenic mutation will not be revealed but some genetic variants (e.g., single nucleotide polymorphisms) with unknown clinical significance and functional consequence, requiring further tests to clarify (e.g. segregation in family members). Therefore, it is important to plan the willing (or not) to communicate results to the family. When a known deleterious mutation is detected in a family member, and when the affected individual agrees to release his/her results to the family, predictive testing can be offered to at-risk relatives.

Predictive testing often requires two pre-test counseling interviews with up to three months between them, when family, emotional, employment and insurance issues are discussed, and as well the mode of inheritance and penetrance of the mutation are explained. Screening and preventive options should also be discussed and it must be stressed that no surveillance guideline is flawless, so individuals must bear in mind that abnormal symptoms should never be ignored between screening exams [32].

\section{Post-test Counseling}

When an affected or unaffected patient chooses to undergo testing, post-test counseling helps individuals to interpret and understand their results, whether positive, negative, undetermined or inconclusive. Psychological support may be provided as ambiguity and uncertainty may arise [31]. For example, individuals with a low-risk result may suffer from "the survivor guilt". High-risk individuals may need to explain positive results to their at-risk closest relatives and counselors (or geneticists) can help sharing this information. It should be emphasized that individuals who have had cancer may be psychologically affected and feel guilty by knowing their pathogenic germ-line mutation may be passed on through their offspring. In addition, since early diagnosis of cancer improves outcome, a clear protocol for surveillance and/or possible prophylactic measures must be offered to those at greater risks,

\begin{tabular}{|c|c|c|c|}
\hline $\begin{array}{l}\text { Clinical criteria/cancer(s) } \\
\text { included }\end{array}$ & Model(s) & $\begin{array}{l}\text { Gene(s) } \\
\text { included }\end{array}$ & Syndrome \\
\hline $\begin{array}{l}\text { Breast cancer (age }<45 \text {, two } \\
\text { primaries, male) } \\
\text { Ovarian cancer } \\
\text { Pancreatic cancer } \\
\text { Prostate cancer } \\
\text { Ashkenazi ancestry } \\
\text { Family history }\end{array}$ & $\begin{array}{l}\text { Couch [5] } \\
\text { Penn II [6] } \\
\text { Myriad [7] } \\
\text { BRCAPRO [8-10] } \\
\text { Tyrer-Cuzick [11] } \\
\text { BOADICEA [12] }\end{array}$ & $\begin{array}{l}\text { BRCA1 } \\
\text { BRCA2 }\end{array}$ & $\mathrm{HBOC}$ \\
\hline $\begin{array}{l}\text { Amsterdam I and II [17] } \\
\text { Bethesda [18] } \\
\text { Colorectal cancer } \\
\text { Endometrial cancer }\end{array}$ & $\begin{array}{l}\text { Wijnen [13] } \\
\text { MMRpro [14] } \\
\text { MMRpredict [15] } \\
\text { PREMM1,2,6 [16] }\end{array}$ & $\begin{array}{l}\text { MLH1 } \\
\text { MSH2 } \\
\text { MSH6 }\end{array}$ & $\begin{array}{l}\text { Lynch/ } \\
\text { HNPCC }\end{array}$ \\
\hline $\begin{array}{l}\text { Classic [19] } \\
\text { Chompret [20] } \\
\text { Adrenocortical, breast, sarcoma, } \\
\text { brain cancer }\end{array}$ & & TP53 & Li-Fraumeni \\
\hline Classic [21] & Cleveland clinic [22] & PTEN & Cowden \\
\hline Melanoma & MELApro [23] & CDKN2A & Melanoma \\
\hline
\end{tabular}

Hereditary Breast and Ovarian Cancer

Table 3: Clinical criteria guidelines and mutation probability models utilized for HCRA. 


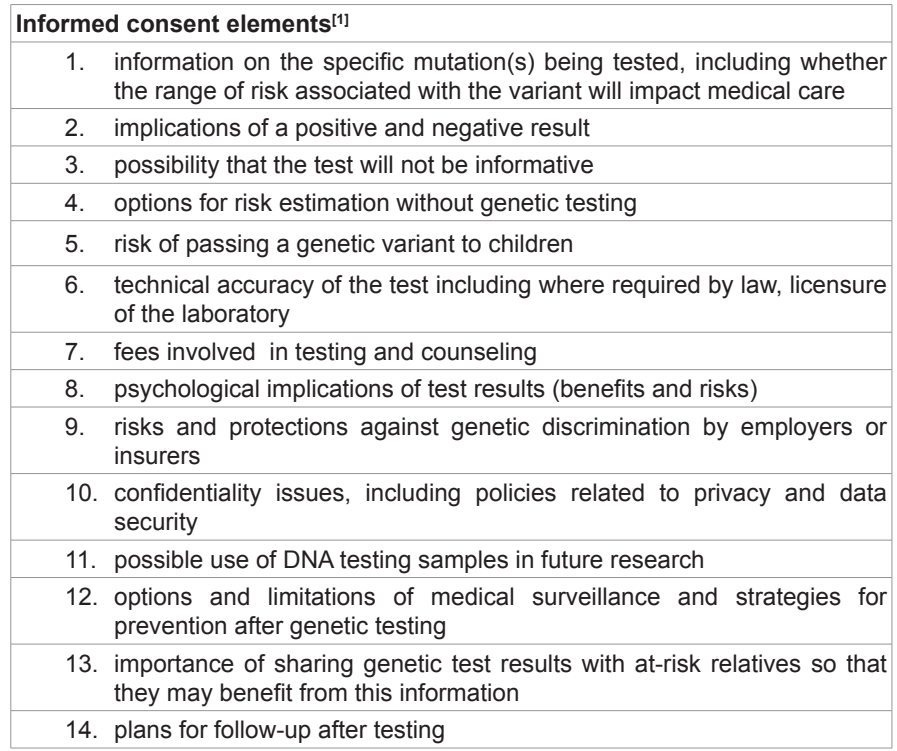

Table 4: Basic elements of informed consent for cancer susceptibility testing.

even if they refuse or could not afford genetic testing. For example, risk-reducing bilateral mastectomy when treating unilateral breast cancer in a BRCA1/BRCA2 mutation carrier or hysterectomy and bilateral salpingo-ooforectomy in a MSH6 mutation carrier. However, the application of such a system requires robust audit of outcomes, both related to cancer morbidity and mortality, and of psychological effects. Establishing a threshold level of risk at which to offer screening is needed in order to assess outcome. Those at moderately increased risk must engage in surveillance strategies whose efficacy (specificity, sensitivity and cost-effectiveness) should be addressed in the long term [31].

In summary, HCRA is a multidisciplinary (with genetic counselors, trained genetic nurses, oncologists, psychologists and social workers) process of estimating probabilities of germ-line mutations in cancer susceptibility genes and assessing empiric risks of cancer based on personal and family histories in order to offer diagnostic and predictive gene testing. Providing patients with pre- and post-test genetic counseling can help them to get informed decision making. Following individuals at increased risk with surveillance protocols (such as from NCCN), reassuring those at low risk, and referring those at high risk of a hereditary cancer to a cancer genetics center with outpatient clinics may be the best suitable approach to HCRA. Specialized nurses can be settled in district hospitals to undertake pedigrees and risk assessment so they can refer those patients with moderately increased risk for surveillance, those with highly increased risk to the local cancer genetics center and reassure patients with low risk [32].

In Brazil, a National Familial Cancer Network has been built in order to provide families with hereditary cancer prompt access to diagnosis, management and counseling of the most common hereditary cancer syndromes in a public health care setting [33].

Collaboration with cancer patients associations and nongovernmental foundations would be extremely helpful to providing families with a better support and care.

\section{References}

1. Robson ME, Storm CD, Weitzel J, Wollins DS, Offit K (2010) American Society of Clinical Oncology American Society of Clinical Oncology policy statement update: genetic and genomic testing for cancer susceptibility. J Clin Oncol 28: 893-901.
2. Trepanier A, Ahrens M, McKinnon W, Peters J, Stopfer J, et al. (2004) Genetic cancer risk assessment and counseling: recommendations of the national society of genetic counselors. J Genet Couns 13: 83-114.

3. Oncology Nursing Society. Role of the Oncology Nurse in Cancer Genetic Counseling.

4. Weitzel JN, Blazer KR, Macdonald DJ, Culver JO, Offit K (2011) Genetics, genomics, and cancer risk assessment: State of the Art and Future Directions in the Era of Personalized Medicine. CA Cancer J Clin .

5. Couch FJ, DeShano ML, Blackwood MA, Calzone K, Stopfer J, et al. (1997) BRCA1 mutations in women attending clinics that evaluate the risk of breast cancer. N Engl J Med 336: 1409-1415.

6. Lindor NM, Johnson KJ, Harvey $\mathrm{H}$, Shane Pankratz V, Domchek SM, et al (2010) Predicting BRCA1 and BRCA2 gene mutation carriers: comparison of PENN II model to previous study. Fam Cancer 9: 495-502.

7. Frank TS, Deffenbaugh AM, Reid JE, Hulick M, Ward BE, et al. (2002) Clinica characteristics of individuals with germline mutations in BRCA1 and BRCA2 analysis of 10,000 individuals. J Clin Oncol 20: 1480-1490.

8. Berry DA, Iversen ES Jr, Gudbjartsson DF, Hiller EH, Garber JE, et al. (2002 BRCAPRO validation, sensitivity of genetic testing of BRCA1/BRCA2, and prevalence of other breast cancer susceptibility genes. J Clin Oncol 20: 27012712.

9. Berry DA, Parmigiani G, Sanchez J, Schildkraut J, Winer E (1997) Probability of carrying a mutation of breast-ovarian cancer gene BRCA1 based on family history. J Natl Cancer Inst 89: 227-238.

10. Parmigiani G, Berry D, Aguilar O (1998) Determining carrier probabilities fo breast cancer-susceptibility genes BRCA1 and BRCA2. Am J Hum Genet 62 145-158.

11. Tyrer J, Duffy SW, Cuzick J (2004) A breast cancer prediction mode incorporating familial and personal risk factors. Stat Med 23: 1111-1130.

12. Antoniou AC, Pharoah PP, Smith P, Easton DF (2004) The BOADICEA model of genetic susceptibility to breast and ovarian cancer. $\mathrm{Br} J$ Cancer 91: 1580-1590.

13. Wijnen JT, Vasen HF, Khan PM, Zwinderman AH, van der Klift $H$, et al. (1998) Clinical findings with implications for genetic testing in families with clustering of colorectal cancer. N Engl J Med 339: 511-518.

14. Chen S, Wang W, Lee S, Nafa K, Lee J, et al. (2006) Prediction of germline mutations and cancer risk in the Lynch syndrome. JAMA 296: 1479-1487.

15. Barnetson RA, Tenesa A, Farrington SM, Nicholl ID, Cetnarskyj R, et al. (2006) Identification and survival of carriers of mutations in DNA mismatch-repair genes in colon cancer. N Engl J Med 354: 2751-2763.

16. Kastrinos F, Steyerberg EW, Mercado R, Balmaña J, Holter S, et al. (2011) The PREMM $(1,2,6)$ model predicts risk of MLH1, MSH2, and MSH6 germline mutations based on cancer history. Gastroenterology 140: 73-81.

17. Vasen HF, Watson P, Mecklin JP, Lynch HT (1999) New clinical criteria for hereditary nonpolyposis colorectal cancer (HNPCC, Lynch syndrome) proposed by the International Collaborative group on HNPCC. Gastroenterology 116:1453-1456.

18. Umar A, Boland CR, Terdiman JP, Syngal S, de la Chapelle A, et al. (2004) Revised Bethesda Guidelines for hereditary nonpolyposis colorectal cancer (Lynch syndrome) and microsatellite instability. J Natl Cancer Inst 96: 261-268.

19. Li FP, Fraumeni JF Jr (1969) Soft-tissue sarcomas, breast cancer, and other neoplasms. A familial syndrome? Ann Intern Med 71: 747-752.

20. Chompret $A$, Brugières $L$, Ronsin $M$, Gardes $M$, Dessarps-Freichey $F$, et al. (2000) P53 germline mutations in childhood cancers and cancer risk for carrier individuals. Br J Cancer 82: 1932-1937.

21. Eng C (2000) Will the real Cowden syndrome please stand up: revised diagnostic criteria. J Med Genet 37: 828-830.

22. Tan MH, Mester J, Peterson C, Yang Y, Chen JL, et al. (2011) A clinical scoring system for selection of patients for PTEN mutation testing is proposed on the basis of a prospective study of 3042 probands. Am J Hum Genet 88: 42-56.

23. Dinh TA, Rosner BI, Atwood JC, Boland CR, Syngal S, et al. (2011) Health benefits and cost-effectiveness of primary genetic screening for Lynch syndrome in the general population. Cancer Prev Res (Phila) 4: 9-22. 
24. Kwon JS, Gutierrez-Barrera AM, Young D, Sun CC, Daniels MS, et al. (2010) Expanding the criteria for BRCA mutation testing in breast cancer survivors. $J$ Clin Oncol 28: 4214-4220.

25. National Comprehensive Cancer (2013) Network NCCN Practice Guidelines V.1: Genetic/Familial High-risk Assessment: Breast and Ovarian. Fort Washington, PA: National Comprehensive Cancer Network.

26. National Comprehensive Cancer Network (2012) NCCN Practice Guidelines V.2: Colorectal Cancer Screening. NCCN Clinical Practice Guidelines in Oncology. V.2.2012. Fort Washington, PA: National Comprehensive Cancer Network.

27. Hampel H, Sweet K, Westman JA, Offit K, Eng C (2004) Referral for cance genetics consultation: a review and compilation of risk assessment criteria. J Med Genet 41: 81-91.
28. Gail MH, Brinton LA, Byar DP, Corle DK, Green SB, et al. (1989) Projecting individualized probabilities of developing breast cancer for white females who are being examined annually. J Natl Cancer Inst 81: 1879-1886.

29. Claus EB, Risch N, Thompson WD (1994) Autosomal dominant inheritance of early-onset breast cancer. Implications for risk prediction. Cancer 73: 643-651.

30. National Cancer Institute (NCI) (2013) Risk Factor Monitoring and Methods.

31.(2008) Genetic counseling: an indispensable step in the genetic testing process. J Oncol Pract 4: 96-98.

32. Hodgson SV, Foulkes WD, Eng C, Maher ER (2007) A practical guide to human cancer genetics. (3rdedn). Cambridge University Press, Cambridge, UK

33. Ministério da Saúde (2009) Instituto Nacional de Câncer (INCA) Rede naciona de câncer familial: manual operacional, Coordenação de Educação (CEDC) Rio de Janeiro, Brazil.
This article was originally published in a special issue, Cancer Genetics handled by Editor(s). Dr. Deb Neklason, Huntsman Cancer Institute at University of Utah, USA 